\author{
СІ. Я. ДЗЮБАНОВСЬКИЙ, Я. В. КАЧАНОВСЬКИЙ, Т. В. ДАЦКО
}

Тернопільський національний медичний університет імені І. Я. Горбачевського МОЗ України

\title{
Ендоскопічно-морфологічна оцінка гемостазу при кровоточивих гастродуоденальних виразках
}

\begin{abstract}
Мета роботи: оцінити ендоскопічні та морфологічні критерії активності кровотечі з прогнозуванням ймовірності її рецидиву за умови хронічної активної гастродуоденальної виразки.

Матеріали і методи. Проаналізовано ендоскопічну картину у 378 хворих із хронічними кровоточивими виразками шлунка та дванадцятипалої кишки за класифікацією Forrest. Пацієнтів чоловічої статі було 257 (67,98 \%), жіночої - 121 (32,02 \%). 3 Forest IA, IB, IIA, IIB, IIC було 231 (61,11 \%) пацієнт, яким проводили ендоскопічний гемостаз (ін'єкційна терапія чи аргоноплазмова коагуляція). У 147 (38,89 \%) пацієнтів гемостаз не проводили через ендоскопічну картину активності кровотечі за Forest III. Біопсію брали з ділянки періульцерозного інфільтрату під час проведення ендоскопічної діагностики перед проведенням гемостазу в день госпіталізації в стаціонар. Гістологічний матеріал фіксували в розчині формаліну, готували мікроскопічні скельця з фарбуванням за гематоксилін і еозин. Обчислення даних дослідження проводили на основі застосування стандартних програмних продуктів обробки інформації “Statistica”.

Результати досліджень та їх обговорення. Порівняльна оцінка методів ендоскопічного гемостазу виявила переваги аргоноплазмової коагуляції над ін'єкційними методами, що може трактуватися як “золотий стандарт” при виборі методу ендоскопічного гемостазу. Перспективою дослідження є вибір хірургічної тактики залежно від прогнозу вірогідностей рецидиву кровотечі, залежно від кількісного відношення репаративних та деструктивних клітин у біоптатах виразкової інфільтрації у хворих із нестійким гемостазом.
\end{abstract}

Ключові слова: ендоскопічний гемостаз; гастродуоденальна виразка; кровотеча.

Постановка проблеми і аналіз останніх досліджень та публікацій. Кровотечі з верхніх відділів шлунково-кишкового тракту за світовою статистикою зустрічаються приблизно у 100 осіб на 100000 тисяч населення щорічно та залишаються одним із звичних гострих хірургічних захворювань, що призводять до госпіталізації [1]. Близько 80 \% випадків припадає на пептичні гастродуоденальні виразки. Попри наявність сучасних засобів зупинки кровотечі смертність залишається високою від 2 до 10 \% [5].

Результати гастроскопії в разі кровотечі оцінюють за допомогою модифікованої класифікації Forrest [2]. 3 ідентифікацією ураження з стигматами високого ризику можливе прогнозування ризику повторної кровотечі, необхідності в хірургічному втручанні [6].

Втім тільки ендоскопічні характеристики не дають змоги встановити характер перебігу виразкового процесу з визначенням ступеня активності деструктивного процесу, а тому і стратифікація ризику повторної кровотечі не $є$ достовірною, що обумовлює доволі високу частоту рецидиву [3]

Вивчення гістологічних особливостей перебігу періульцерозного процесу кровоточивої виразки дасть змогу з високою ймовірністю судити про ступінь альтерації та разом із ендоскопічними стигматами визначати лікувальну тактику в разі первинних та рецидивних кровоточивих гастродуоденальних виразок [4].

Мета роботи: оцінити ендоскопічні та морфологічні критерії активності кровотечі з прогнозуванням ймовірності іï рецидиву за умови хронічної активної гастродуоденальної виразки.

Матеріали і методи. Проаналізовано ендоскопічну картину у 378 хворих із хронічними кровоточивими виразками шлунка та дванадцятипалої кишки (ДПК) за класифікацією Forrest. Пацієнтів чоловічої статі було 257 (67,98 \%), жіночої - 121 (32,02 \%). Розподіл за віком та ступенем крововтрати залежно від ендоскопічної картини наведено в таблицях 1 i 2.

Розподіл за типом активності кровотечі наведено в таблиці 3.

3 Forest IA, IB, IIA, IIB, IIC було - 231 (61,11 \%) пацієнтів, яким проводили ендоскопічний гемостаз (ін'єкційна терапія чи аргоноплазмова коагуляція) (табл. 4). У 147 (38,89 \%) пацієнтів гемостаз не проводили через ендоскопічну картину активності кровотечі за Forest III.

Біопсію брали з ділянки періульцерозного інфільтрату під час проведення ендоскопічної діагностики перед проведенням гемостазу в день госпіталізації в стаціонар. Гістологічний матеріал фіксували в розчині формаліну, готували мікроскопічні скельця з фарбуванням за гематоксилін і еозин. 
Таблиця 1. Розподіл пацієнтів за віком відповідно до ендоскопічної картини Forrest (n=378)

\begin{tabular}{|c|c|c|c|c|}
\hline \multirow{2}{*}{ Стигмати за Forrest } & \multicolumn{3}{|c|}{ Вік (років) } & \multirow{2}{*}{ Всього } \\
\hline & $20-59$ & $60-74$ & 75-89 & \\
\hline F IA & 16 & 5 & 2 & 23 \\
\hline F IB & 20 & 6 & 3 & 29 \\
\hline F IC & 2 & 1 & - & 3 \\
\hline F IIA & 38 & 9 & 6 & 53 \\
\hline F IIB & 41 & 8 & 6 & 55 \\
\hline F IIC & 24 & 7 & 3 & 34 \\
\hline F III & 132 & 32 & 17 & 181 \\
\hline Всього & $273(72,2 \%)$ & $68(18,0 \%)$ & $37(9,8$ \%) & $378(100 \%)$ \\
\hline
\end{tabular}

Таблиця 2. Ендоскопічні стигмати за Forrest і ступені крововтрати

\begin{tabular}{||l|c|c|c|c||}
\hline \hline Стигмати за Forrest & I ст. & II ст. & III ст. & Всього \\
\hline F IA & 6 & 10 & 7 & 23 \\
\hline F IB & 8 & 12 & 1 & 3 \\
\hline F IC & 1 & 1 & 17 & 53 \\
\hline F IIA & 15 & 21 & 18 & 55 \\
\hline F IIB & 16 & 21 & 11 & 34 \\
\hline F IIC & 9 & 14 & 57 & 181 \\
\hline F III & 47 & 77 & $120(31,7 \%)$ & $378(100 \%)$ \\
\hline Всього & $102(27,0 \%)$ & $156(41,3 \%)$ & 9 & 29 \\
\hline \hline
\end{tabular}

Таблиця 3. Розподіл пацієнтів за типом кровотечі (Forrest)

\begin{tabular}{||l|c||}
\hline \multicolumn{1}{|c|}{ Стигмати за Forrest } & Ендоскопічна картина, абс. (\%) \\
\hline F IA & $27(7)$ \\
\hline F IB & $41(11)$ \\
\hline F IIA & $62(16)$ \\
\hline F IIB & $63(17)$ \\
\hline F IIC & $38(10)$ \\
\hline F III & $147(39)$ \\
\hline Всього & $378(100)$ \\
\hline
\end{tabular}

Таблиця 4. Розподіл пацієнтів за типом ендоскопічного гемостазу

\begin{tabular}{||l|c|c|c|c|c||}
\hline \multicolumn{1}{|c|}{ Тип ендоскопічного гемостазу } & F IA & F IB & F IIA & F IIB & F IIC \\
\hline Ендоскопічно-ін'єкційна терапія $(\mathrm{n}=177)$ & 22 & 34 & 50 & 41 & 30 \\
\hline Ендоскопічна аргоноплазмова коагуляція $(\mathrm{n}=54)$ & 5 & 7 & 12 & 22 & 8 \\
\hline
\end{tabular}




\section{З ДОСВІДУ РОБОТИ}

Обчислення даних дослідження проводили на основі застосування стандартних програмних продуктів обробки інформації “Statistica”.

Результати досліджень та їх обговорення. На основі аналізу біопсійного матеріалу визначено такі морфологічні типи хронічних гастродуоденальних виразок:

- тип 1 - у дослідному матеріалі краю хронічної виразки шлунка виявлено значні склеротичні зміни строми навколо залоз у слизовій оболонці. Залози залишались переважно округлої форми. Частина епітеліоцитів мали прояви білкової дистрофії із поодинокими вогнищевими некрозами. Прояви гіперплазії та дисплазії відсутні. Також візуалізувався помірний набряк строми із вогнищевою лімфо-гістіоцитарною інфільтрацією. Стінка судин великого та середнього калібру склерозована, місцями із проявами мукоїдного та фібриноїдного набряку та із формуванням пристінкових тромбів (рис. 1). Судини дрібного калібру із вогнищевими еритростазами.

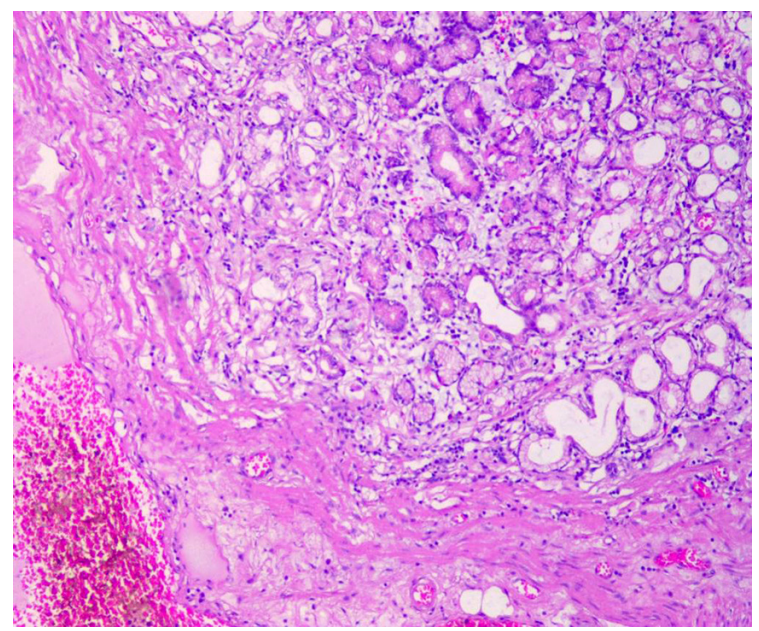

Рис. 1. Стінка хронічної виразки шлунка. Склероз та гіаліноз судин великого калібру, вогнищеві еритростази судин дрібного калібру. Забарвлення гематоксиліном та еозином. х 100.

Такі структурні прояви можна віднести до активно прогресуючих, а саме:

- з високим, помірним або низьким темпами наростання деструкції (без тенденції до зупинки кровотечі та з ризиком спонтанного відновлення геморагії) - характеризуються первинно-низьким, наростаючим дефіцитом захисних чинників, пригніченням регенерації та дефіцитом пластичних резервів судинного русла за рахунок ураження великих артерій та значних розладів мікроциркуляції. Поширенням деструктивно-некробіотичних процесів на органному рівні. Дані гістологічні змі- ни встановлено у 46 (67,6 \%) пацієнтів з ендоскопічним класом кровотечі за Forrest IA IB.

- тип 2 - гістологічне дослідження стінки хронічної виразки шлунка виявило помірні склеротичні зміни строми навколо залоз у слизовій оболонці. Залози мали дещо видовжену або округлу форму (рис. 2). Строма навколо залоз залишалась значною, із помірним набряком та вогнищевою лімфо-гістіоцитарною інфільтрацією. Судини дрібного калібру дещо розширювались, були повнокровними, із поодинокими периваскулярними еритродіапедезами. Такі морфологічні прояви можуть спричиняти гіпоксію в ділянках базальних мембран, що порушує трофіку епітелію залоз і призводить до розвитку дистрофічних змін в епітеліоцитах. В більшості епітеліоцитів залоз підвищувалась секреторна активність. Лише в поодиноких епітеліоцитів візуалізувались незначні дистрофічні зміни. Прояви гіперплазії та дисплазії клітин не спостерігались. Стінка судин великого та середнього калібру не потовщувались, в окремих полях зору спостерігались прояви мукоїдного набряку. Судини дрібного калібру із вогнищевими еритростазами.

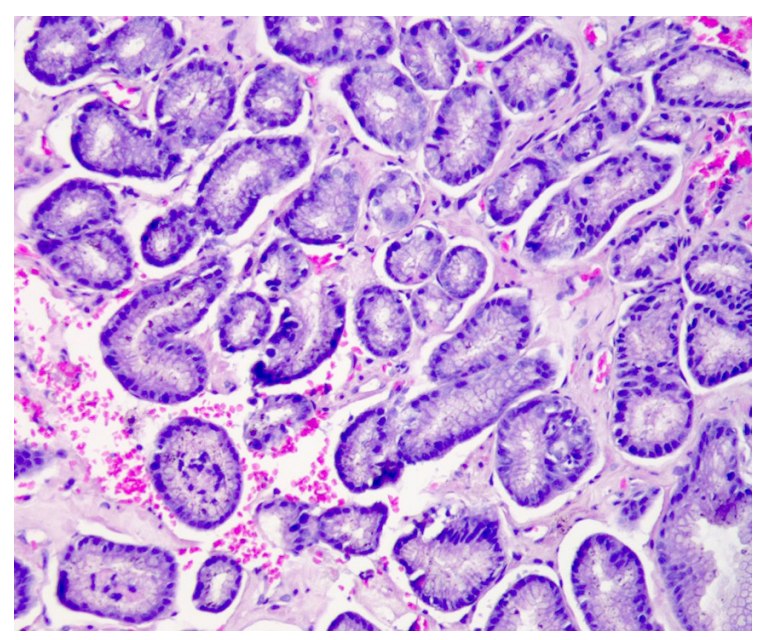

Рис. 2. Стінка хронічної виразки шлунка. Помірний набряк строми, вогнищеві еритродіапедези. Забарвлення гематоксиліном та еозином. х 200.

Такі структурні прояви можна віднести до активно прогресуючих, а саме: активних із затухаючим перебігом (без схильності до рецидиву геморагії), у яких захисні та репаративні процеси різко активовані, а розлади мікроциркуляції несуттєві внаслідок ураження дрібних артерій, що зумовлює обмеження деструктивних процесів на клітинному та тканинному рівнях. Дані гістологічні зміни встановлені у 84 (52,0 \%) \% пацієнтів з ендоскопічним класом кровотечі за Forrest IIA IIB. 


\section{З ДОСВІДУ РОБОТИ}

- тип 3 - гістологічне дослідження слизової оболонки із стінки хронічної виразки шлунка виявило помірно-виражені склеротичні зміни строми навколо залоз. Залози мали дещо видовжену або округлу форму (рис. 3), помірно збільшувались у розмірах. В епітелії залоз спостерігається підвищена проліферація, в окремих полях зору із проявами слабкої дисплазії. В поверхневому епітелії візуалізувалась метаплазія за тонкокишковим типом. Судини дрібного та середнього калібру дещо розширювались, залишались повнокровними, проте периваскулярних еритродіапедезів не спостерігалось. В ділянках базальних мембран епітелію залоз візуалізувався периваскулярний набряк. В більшості епітеліоцитів залоз підвищувалась секреторна активність. Стінка судин великого та середнього калібру дещо потовщувалась, в окремих полях зору спостерігались прояви мукоїдного набряку та пристінкової агрегації еритроцитів.

Такі структурні прояви можна віднести до активно прогресуючих, а саме: активні з вираженою проліферацією в анамнезі (Forest III) -116 (79,0 \%).

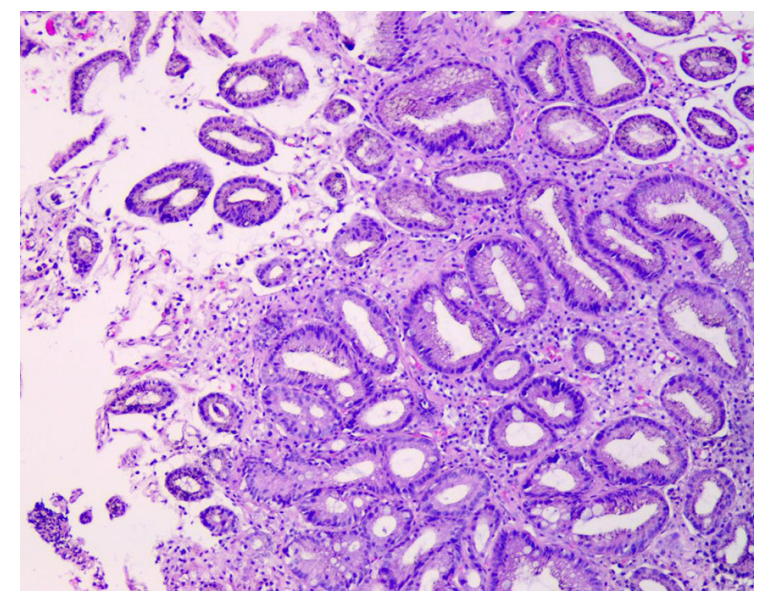

Рис. 3. Стінка хронічної виразки шлунка. Збільшення розмірів залоз, гіперплазія та слабка дисплазія епітелію. В судинах пристінкова агрегація еритроцитів. Забарвлення гематоксиліном та еозином. х 200.

Проведено аналіз частоти рецидиву кровотечі залежно від типу ендоскопічного гемостазу та у випадку, якщо його не проводили (табл. 5).

Таблиця 5. Частота рецидиву кровотечі залежно від стигмат за Forrest і ендоскопічного гемостазу

\begin{tabular}{||l|c|c|c|c|c|c|c|c||}
\hline \hline \multirow{2}{*}{ Ендоскопічний гемостаз } & \multicolumn{7}{|c||}{ Стигмати кровотечі } & \multirow{2}{*}{ Всього } \\
\cline { 2 - 9 } & F IA & F IB & F IC & F IIA & F IIB & F IIC & F III & \\
\hline $\begin{array}{l}\text { Ендоскопічний гемостаз } \\
\text { проводився }\end{array}$ & $18(1)$ & $22(1)$ & $3(2)$ & $37(10)$ & $38(9)$ & $24(2)$ & $89(1)$ & $231(26)$ \\
\hline $\begin{array}{l}\text { Ендоскопічний гемостаз } \\
\text { не проводився }\end{array}$ & $4(2)$ & $5(2)$ & - & $16(13)$ & $17(9)$ & $9(2)$ & $94(1)$ & $147(29)$ \\
\hline Всього & $22(3)$ & $27(3)$ & $3(2)$ & $53(23)$ & $55(18)$ & $33(4)$ & $183(2)$ & $378(55)$ \\
\hline \hline
\end{tabular}

Примітка: в дужках вказано кількість рецидивів кровотечі.

Висновок. Порівняльна оцінка методів ендоскопічного гемостазу виявила переваги аргоноплазмової коагуляції над ін’єкційними методами, що може трактуватися як “золотий стандарт” при виборі методу ендоскопічного гемостазу. Перспек- тивою дослідження є вибір хірургічної тактики залежно від прогнозу вірогідностей рецидиву кровотечі, залежно від кількісного відношення репаративних та деструктивних клітин у біоптатах виразкової інфільтрації у хворих із нестійким гемостазом.

\section{СПИСОК ЛІТЕРАТУРИ}

1. Feinman M. Upper gastrointestinal bleeding / M. Feinman, E. R. Haut // Surg. Clin. North Am. - 2014. - Vol. 94 (1). - P. $43-53$. 2. The role of endoscopy in diagnosis and treatment of gastroduodenal bleedings / A. M. Khadzhibaev, R. M. Iu, R. M. Kholmatov [et al.] // Khirurgiia. - 2005. - Vol. (4). - P. 24-27.

3. Predictors of early rebleeding after endoscopic therapy in patients with nonvariceal upper gastrointestinal bleeding secondary to high-risk lesions / D. Maggio, A. N. Barkun, M. Martel [et al.]
// Can. J. Gastroenterol. - 2013. - Vol. 27, No. 8. - P. 454-458. 4. Морфологічні особливості слизових оболонок шлунка та дванадцятипалої кишки у хворих на виразкову хворобу, ускладнену гострою рецидивною шлунково-кишковою кровотечею / Ю. С. Семенюк, П. Я. Боднар, В. Г. Мініч // Вісник наукових досліджень. - 2013. - № 4. - С. 49-50.

5. Stanley A. J. Management of acute upper gastrointestinal bleeding / A. J. Stanley, L. Laine // BMJ. - 2019. - Vol. 364. 


\section{З ДОСВІДУ РОБОТИ}

6. Second-look endoscopy with thermal coagulation or injections for peptic ulcer bleeding: A meta-analysis / K. K. Tsoi,
H. C. Chan, P. W. Chiu [et al.] // Journal of Gastroenterology and Hepatology. - 2010. - Vol. 25 (1). - Vol. 8-13.

\section{REFERENCES}

1. Feinman, M., \& Haut, E.R. (2014). Upper gastrointestinal bleeding. Surg. Clin. North Am., 94 (1), 43-53.

2. Khadzhibaev, A.M., Iu, R.M., Kholmatov, R.M., Melnik, I.V., \& Allaiarov, U. D. (2005). The role of endoscopy in diagnosis and treatment of gastroduodenal bleedings. Khirurgiia, (4), 24-27.

3. Maggio, D., Barkun, A.N., \& Martel, M. (2013). Predictors of early rebleeding after endoscopic therapy in patients with nonvariceal upper gastrointestinal bleeding secondary to high-risk lesions. Can. J. Gastroenterol., 27 (8), 454-458.

4. Semeniuk, Yu.S., Bodnar, P.Ya., \& Minich, V.H. (2013). Morfolohichni osoblyvosti slyzovykh obolonok shlunka ta dvanadtsi- atypaloi kyshky u khvorykh na vyrazkovu khvorobu, uskladnenu hostroiu retsydyvnoiu shlunkovo-kyshkovoiu krovotecheiu [Morphological features of the mucous membranes of the stomach and duodenum in patients with peptic ulcer disease complicated by acute recurrent gastrointestinal bleeding]. Visnyk naukovykh doslidzhen - Bulletin of Scientific Research, (4), 49-50 [in Ukrainian]. 5. Stanley, A.J., \& Laine, L. (2019). Management of acute upper gastrointestinal bleeding. BMJ, 364 .

6. Tsoi, K.K., Chan, H.C., Chiu, P.W., Pau, C.Y., Lau, J.Y., \& Sung, J.J. (2010). Second-look endoscopy with thermal coagulation or injections for peptic ulcer bleeding: A meta-analysis. Journal of Gastroenterology and Hepatology, 25 (1), 8-13.

Отримано 02.07.2021

Електронна адреса для листування: kachanovskyi_iav@tdmu.edu.ua

I. YA. DZIUBANOVSKYI, YA. V. KACHANOVSKY, T. V. DATSKO

I. Horbachevsky Ternopil National Medical University

\section{ENDOSCOPIC-MORPHOLOGICAL ASSESSMENT OF HEMOSTASIS IN BLEEDING GASTRODODENAL ULCERS}

The aim of the work: to evaluate endoscopic and morphological criteria of bleeding activity with prediction of the probability of its recurrence in the case of chronic active gastroduodenal ulcer.

Materials and Methods. The endoscopic picture in 378 patients with chronic bleeding ulcers of the stomach and duodenum according to the Forrest classification was analyzed. There were 257 male patients (67.98 \%) and 121 female patients (32.02 \%). Of Forest IA, IB, IIA, IIB, IIS, there were 231 (61.11\%) patients who underwent endoscopic hemostasis (injection therapy or argonoplasmic coagulation). In 147 (38.89 \%) patients, hemostasis was not performed due to the endoscopic picture of bleeding activity in Forest III. Biopsy was taken from the area of periulcerative infiltrate during endoscopic diagnosis before hemostasis on the day of admission to the hospital. Histological material was fixed in formalin solution, prepared microscopic slides stained with hematoxylin and eosin. The calculation of the study data was performed on the basis of the use of standard software products "Statistica".

Results and Discussion. A comparative evaluation of endoscopic hemostasis methods revealed the advantages of argonoplasmic coagulation over injection methods, which can be interpreted as the "gold standard" when choosing the method of endoscopic hemostasis. The prospect of the study is the choice of surgical tactics depending on the prognosis of the likelihood of recurrence of bleeding, depending on the quantitative ratio of reparative and destructive cells in biopsies of ulcerative infiltration in patients with unstable hemostasis.

Key words: endoscopic hemostasis; gastroduodenal ulcer; bleeding. 